\title{
PERENCANAAN CAMPURAN MATERIAL SEBAGAI LAPIS PONDASI ATAS
}

\section{JALAN}

\author{
Frisca Natalia Matwear \\ Program Studi Teknik Sipil Universitas Muhammadiyah Sorong \\ Jalan Pendidikan No 27 Kota Sorong, Propinsi Papua Barat \\ Email :friscamatwear926@gmai.com
}

\begin{abstract}
ABSTRAK
Jalan raya adalah jalur-jalur tanah di atas permukaan bumi yang dibuat oleh manusia dengan bentuk, ukuran-ukuran dan jenis konstruksinya sehingga dapat digunakan untuk menyalurkan lalu lintas orang, hewan dan kendaraan yang mengangkut barang dari suatu tempat ke tempat lainnya dengan mudah dan cepat. Perencanaan jalan raya yang baik tentunya tidak lepas dari kekuatan pondasi jalan raya yaitu lapis tanah dasar, lapis pondasi bawah dan lapis pondasi atas. Lapisan perkerasan jalan berfungsi untuk menerima beban lalu-lintas dan menyebarkannya ke lapisan di bawahnya terus ke tanah dasar. Jika pondasi jalan raya tidak memenuhi standar yang ditetapkan, pasti akan berdampak buruk bagi kekuatan yang dapat mengakibatkan kerusakan pada jaan raya. Oleh karena itu, perlu adanya perencanaan yang baik terhadap pondasi jalan raya. Salah satu yang akan dibahas oleh penulis adalah lapis pondasi atas. Lapis pondasi adalah bagian dari perkerasan yang terletak antara lapis permukaan dan lapis pondasi bawah. Dari latar belakang diatas peneliti akan melakukian penelitian dengan judul "PERENCANAAN CAMPURAN MATERIAL SEBAGAI LAPIS PONDASI ATAS JALAN". Tujuannya agar jalan raya yang dibangun tidak mengalami kerusakan dan layak untuk digunakan. Metode penelitian ini diuji di laboratorium, yaitu untuk mengetahui nilai CBR.
\end{abstract}

Kata Kunci : jalan raya; pondasi ; lalu lintas 


\section{PENDAHULUAN}

\section{Latar Belakang}

Jalan raya adalah jalur-jalur tanah di atas permukaan bumi yang dibuat oleh manusia dengan bentuk, ukuran-ukuran dan jenis konstruksinya sehingga dapat digunakan untuk menyalurkan lalu lintas orang, hewan dan kendaraan yang mengangkut barang dari suatu tempat ke tempat lainnya dengan mudah dan cepat. Perencanaan jalan raya yang baik tentunya tidak lepas dari kekuatan pondasi jalan raya yaitu lapis tanah dasar, lapis pondasi bawah dan lapis pondasi atas. Lapisan perkerasan jalan berfungsi untuk menerima beban lalu-lintas dan menyebarkannya ke lapisan di bawahnya terus ke tanah dasar. Jika pondasi jalan raya tidak memenuhi standar yang ditetapkan, pasti akan berdampak buruk bagi kekuatan yang dapat mengakibatkan kerusakan pada jaan raya. Oleh karena itu, perlu adanya perencanaan yang baik terhadap pondasi jalan raya. Salah satu yang akan dibahas oleh penulis adalah lapis pondasi atas. Lapis pondasi adalah bagian dari perkerasan yang terletak antara lapis permukaan dan lapis pondasi bawah. Fungsi lapis ini adalah lapis pendukung bagi lapis permukaan, bagian perkerasan yang menahan gaya lintang dari beban roda dan menyebarkan beban ke lapisan dibawahnya dan lapisan peresapan untuk lapisan pondasi bawah. Bahan-bahan untuk lapis pondasi atas ini harus cukup kuat dan awet sehingga dapat menahan beban-beban roda. Dalam penentuan bahan lapis pondasi ini perlu dipertimbangkan beberapa hal antara lain, kecukupan bahan setempat, harga, volume pekerjaan dan jarak angkut bahan ke lapangan. Dari latar belakang diatas peneliti akan melakukian penelitian dengan judul " PERENCANAAN CAMPURAN MATERIAL SEBAGAI LAPIS PONDASI ATAS JALAN”. Tujuannya agar jalan raya yang dibangun tidak mengalami kerusakan dan layak untuk digunakan.

\section{STATE OF THE ART}

Adapun penelitian terdahulu yang terkait dengan penelitian ini adalah sebagai berikut :

1. Menurut Mita Lestari, M. Ikhwan Yani, dan Suradji Gandi (2016) menyebutkan hasil penelitiannya adalah tentang Analisis Lapis Pondasi Jalan Dengan Campuran Material Bervariasi Tinjauan California Bearing Ratio (CBR). Dari penelitian ini di dapatkan hasil-hasil sebagai berikut :

1. Hasil pemeriksaan sifat fisik penguji abrasi/keausan terhadap agregat kasar dari lokasi daerah Desa Pulorejo, Desa Sibumg/Saing dan Tangkiling didapat nilai rata-rata keausan untuk masing-masing agregat kasar yaitu Batu Palurejo =41,22\%, Batu Sibung?Saing $=30,51 \%$ dan Batu Tangkiling $=32,23 \%$ dengan nilai keausan yang memenuhi syarat spesifikasi lapis pondasi Agregat kelas A $(<40 \%)$. Untuk lokasi Pulerejo tidak memenuhi spesifikasi dengan nilain $41,22 \%>40 \%$.

2. Hasil pengujian untuk batu dari 3 lokasi yaitu daerah Desa Pulorejo, Desa Sibung/Saing dan Tangkiling, hanya ada dua lokasi daerah yang memenuhi syarat untuk lapis pondasi agregat base kelas A yaitu Desa Sibung/Saing dan Tangkiling, dengan komposisi campuran yang nilai CBRnya memenuhi spesifikasi base A adalah komposisi II (60\% batu $+30 \%$ abu batu $+10 \%$ pasir) karena dapat kita lihat dari ketiga komposisi yang dibuat jika abu batu di tambah dengan kadar tertentu maka nilai CBR akan meningkat, sedangkan jika pasir ditambah dan abu batu dikurang maka nilai CBR akan menurun. Karena daya ikat abu batu lebih besar dari daya ikat pasir terhadap batu.

3. Dari nilai CBR yang dihasilkan dari 3 lokasi daerah dapat diketahui selisih nilai antara ketiga daerah yaitu:
a. Palurejo-Sibung/Saing selisihnya $12,73 \%$
b. Palurejo-Tangkiling selisihnya $12,56 \%$
c. Sibung/Saing-Tangkiling selisihnya $0,17 \%$.

2. Menurut Fadly Achmad (2016) mengatakan dalam penelitiannya tentang Tinjauan Material Lokal Quarry Inengo Sebagai Bahan Lapis Pondasi Atas Menurut Spesifikasi Bina Marga 2010. Dari penelitian ini didapatkan hasil-hasil sebagai berikut :

1. Hasil penelitian menunjukkan bahwa nilai abrasi $=25,54 \%$ bidang pecah $81,94 \%, L L=13 \%, P I$ $=5,13 \%$, CBR soaked $=95 \%$ sementara $\gamma_{\mathrm{d}}$ maks $=2,25 \mathrm{gr} / \mathrm{cm}^{3}$ dan $\mathrm{w}_{\text {opt }}=5,90 \%$.

2. Material dari quarry Inengo tidak memenuhi syarat spesifikasi umum 2010 revisi 3 terutama pada gradasi dan butiran pecah. 


\section{METODE}

Tahapan penelitian yang digunakan adalah sebagai berikut :

Metode penelitian ini diuji di laboratorium, yaitu untuk mengetahui nilai CBR.

Semua metode penulisan dan analisa dalam artikel ilmiah ini merujuk pada panduan penulisan tugas akhir Fakultas Teknik Universitas Muhammadiyah Sorong tahun 2014 (Pristianto, Amri, \& Rusdi, 2014).

\section{REFERENSI}

1. Fadly Achmad (2016). Tinjauan Material Lokal Quarry Inengo Sebagai Bahan Lapis Pondasi Atas Menurut Spesifikasi Bina Marga 2010.

2. Mita Lestari, M. Ikhwan Yani, dan Suradji Gandi (2016). Analisis Lapis Pondasi Jalan Dengan Campuran Material Bervariasi Tinjauan California Bearing Ratio (CBR).

3. Pristianto, H., Amri, I., \& Rusdi, A. (2014, May 9). Pedoman Penulisan Tugas Akhir Fakultas Teknik Universitas Muhammadiyah Sorong 2014. http://doi.org/10.17605/OSF.IO/4VTJM.

4. SNI Revisi Dari 03 - 1964 - 1990 Ke 1964 - 2008 Metode Pengujian Berat Jenis Tanah.

5. SNI Revisi Dari 03 - 1965 - 1990Ke 1965 - 2008 Metode pengujian Kadar Air.

6. SNI Revisi Dari 03 - 1966 - 1990 Ke 1966 - 2008 Metode Pengujian Batas plastis.

7. SNI Revisi Dari 03 - 1967 - 1990 Ke 1967 - 2008 Metode Pengujian Batas Cair Dengan Alat Cassagrande.

8. SNI Revisi Dari 03 - 3423 - 1994 Ke 3423 - 2008 Metode pengujian Analisis Ukuran Butir Tanah Dengan Alat Hidrometer. 